\title{
PODATEK OD WYDOBYCIA NIEKTÓRYCH KOPALIN - NOWA JAKOŚĆ W POLSKIM PRAWIE PODATKOWYM
}

\section{UWAGI WPROWADZAJACE}

W dniu 18 kwietnia 2012 r. weszła w życie ustawa o podatku od wydobycia niektórych kopalin ${ }^{1}$, na mocy której do polskiego systemu prawnego wprowadzona została nowa danina publiczna; w myśl przyjętych założeń stanowić ma formę renty surowcowej, czyli ekonomicznego ekwiwalentu dochodów uzyskiwanych $\mathrm{w}$ związku z korzystaniem z dóbr naturalnych będących własnością Skarbu Państwa ${ }^{2}$. Warto przy tym zwrócić uwagę, że zapowiedzi dotyczące rzeczonego instrumentu finansowego pojawiły się już w listopadzie ubiegłego roku w exposé Prezesa Rady Ministrów ${ }^{3}$, dochody zaś z tego źródła uwzględnione zostały w prognozie dochodów budżetu państwa na rok $2012^{4}$.

Wprowadzony podatek dotyczy wydobycia dwóch metali: miedzi (ze względu na ogromne zapotrzebowanie i stosunkowo małe zasoby naturalne będącej surowcem strategicznym) oraz srebra (które występuje w dolnośląskich złożach miedzi $)^{5}$. Podkreślić również należy, że podatek od wydobycia niektórych kopalin należy do grupy danin nakładanych od wielkości urobku (wydobycia) i w całości stanowić ma dochód budżetu państwa. Zdaniem projektodawców powinien on pozwolić na ,uchwycenie nadzwyczajnych zysków podmiotów wydobywających miedź i srebro" ${ }^{6}$, jednak w ocenie doktryny prawa podatkowego i ekspertów z zakresu gospodarki tymi surowcami konstrukcja przedmiotowej daniny budzi liczne wątpliwości. Celem niniejszego artykułu jest przedstawienie elementów technicznych podatku od wydobycia niektórych kopalin oraz kontrowersji, jakie wiążą się z wprowadzeniem tej daniny. Stan prawny przyjęto na dzień 16 kwietnia 2012 r.

${ }^{1}$ Ustawa z 2 marca 2012 r. o podatku od wydobycia niektórych kopalin, Dz. U. 2012, poz. 362.

${ }^{2}$ Uzasadnienie projektu ustawy o podatku od wydobycia niektórych kopalin, druk sejmowy nr 144. Szerzej na temat danin związanych z wydobyciem kopalin zob. Income Taxes, Mining Taxes and Mining Royalties. A Summary of Selected Countries, December 2010, www.pwc.com.

${ }^{3}$ Zob. Exposé premiera Donalda Tuska, Warszawa, 18 listopada 2011 r., http://www.premier. gov.pl/files/download/5677.pdf.

${ }^{4} \mathrm{~W}$ załączniku nr 1 do ustawy budżetowej na rok 2012 z 2 marca 2012 r. (Dz. U. 2012, poz. 273) dochody z tytułu podatku od wydobycia niektórych kopalin zaplanowano w wysokości 1,8 mld zł.

${ }^{5}$ Zob. D. M. Korzeniowska, Analiza obciażen fiskalnych zwiazanych $z$ wydobyciem kopalin w wybranych krajach, Kancelaria Senatu Biuro Analiz i Dokumentacji, www.senat.gov.pl.

${ }^{6}$ Zob. uzasadnienie projektu ustawy o podatku od wydobycia niektórych kopalin, druk sejmowy nr 144. 


\section{ZAKRES PODMIOTOWY PODATKU}

Zgodnie z treścią ustawy o podatku od wydobycia niektórych kopalin podatnikiem tego podatku jest osoba fizyczna, osoba prawna oraz jednostka organizacyjna niemająca osobowości prawnej, dokonująca w zakresie prowadzonej działalności gospodarczej wydobycia miedzi oraz srebra ${ }^{7}$. Przepis określający zakres podmiotowy podatku zawiera zatem normę o charakterze generalnym, jednak w sferze faktycznej jedynym podmiotem podlegającym opodatkowaniu jest KGHM Polska Miedź S.A., będący obecnie monopolistą w sektorze wydobycia rud miedzi ${ }^{8}$. Dodać należy, że Skarb Państwa jest właścicielem 31,79\% akcji w tej spółce, w związku z czym uczestniczy w podziale dywidendy ${ }^{9}$, a pozostała część pozostaje w rękach polskich i zagranicznych akcjonariuszy, tworząc tak zwany free float ${ }^{10}$. Warto także zaznaczyć, że zgodnie ze stanem na 12 stycznia 2012 r. ośmiu podmiotom przyznano koncesje na poszukiwanie złóż.

Organami podatkowymi właściwymi w zakresie podatku od niektórych kopalin są naczelnik urzędu celnego oraz dyrektor izby celnej, właściwi bądź ze względu na adres siedziby podatnika - w przypadku osób prawnych oraz jednostek organizacyjnych nieposiadających osobowości prawnej, bądź ze względu na miejsce zamieszkania podatnika - w odniesieniu do osób fizycznych. Jeżeli nie można ustalić właściwości miejscowej w wyżej określony sposób, organami podatkowymi są Naczelnik Urzędu Celnego w Legnicy oraz Dyrektor Izby Celnej we Wrocławiu ${ }^{11}$. Jednocześnie minister finansów upoważniony został do określenia, w drodze rozporządzenia, wykazu urzędów celnych i izb celnych, których odpowiednio naczelnicy i dyrektorzy są właściwi w zakresie spraw dotyczących podatku, a także terytorialnego zasięgu ich działania. Dodać należy, że ze względu na liczbę ewentualnych podatników w treści przedłożonego projektu rozporządzenia wskazano tylko jeden urząd celny i jedną izbę celną: Urząd Celny w Legnicy i Izbę Celną we Wrocławiu ${ }^{12}$.

Ustawa zawiera również regulacje zobowiązujące właściwego naczelnika urzędu celnego do prowadzenia rejestru podatników. Dane zawarte w przedmio-

\footnotetext{
${ }^{7}$ Art. 4 ustawy o podatku od wydobycia niektórych kopalin.

8 „Kombinat Górniczo-Hutniczy Miedzi” w budowie powstał w 1961 r. W 1968 r. Minister Przemysłu Ciężkiego ostatecznie ustalił nazwę przedsiębiorstwa na „Kombinat Górniczo-Hutniczy Miedzi”. Począwszy od 12 września 1991 r., KGHM Polska Miedź S.A. jest spółką akcyjna, a od lipca 1997 r. jej akcje notowane sa na Giełdzie Papierów Wartościowych w Warszawie, http://www.kghm.pl/index. dhtml?category_id $=190$.

${ }^{9}$ W myśl art. 111 pkt 4 ustawy z 27 sierpnia 2009 r. o finansach publicznych (Dz. U. Nr 157, poz. 1240 ze zm.) dochodami budżetu państwa są m.in. wpłaty z tytułu dywidendy. W $2012 \mathrm{r}$. KGHM Polska Miedź S.A. zasilił budżet państwa wpłatą z tytułu dywidendy w wysokości $190 \mathrm{mln}$ zł (zob. Analiza wykonania budżetu państwa i założeń polityki pieniężnej w 2010 r., s. 63, http://www.nik.gov.pl/ plik/id,2859.pdf ).

${ }^{10}$ Akcjonariat, http://www.kghm.pl/index.dhtml?category_id $=178$.

${ }^{11}$ Art. 11 ustawy o podatku od wydobycia niektórych kopalin.

${ }^{12}$ Zgodnie $\mathrm{z}$ przedłożonym projektem rozporządzenia w sprawie wykazu terytorialnego zasięgu działania urzędów celnych i izb celnych, których odpowiednio naczelnicy i dyrektorzy są właściwi w zakresie spraw dotyczących podatku od wydobycia niektórych kopalin, terytorialny zasięg działania Izby Celnej we Wrocławiu i Urzędu Celnego w Legnicy obejmuje cały kraj. Zob. uzasadnienie projektu ustawy o podatku od wydobycia niektórych kopalin, druk sejmowy nr 144.
} 
towym rejestrze uzyskiwane będą na podstawie informacji przekazywanych ministrowi finansów przez organ wydający koncesję na wydobycie miedzi oraz srebra, czyli ministra właściwego do spraw środowiska ${ }^{13}$, który zobowiązany został do informowania ministra finansów o wydaniu, zmianie treści, wygaśnięciu oraz cofnięciu koncesji na wydobycie miedzi i srebra, a także o ich treści $\mathrm{w}$ terminie $7 \mathrm{dni}$ od dnia zaistnienia powyższych zdarzeń ${ }^{14}$. Warto także zwrócić uwagę, że do ordynacji podatkowej dodano przepis, zgodnie z którym nie zawiadamia się o zamiarze wszczęcia kontroli podatkowej, jeżeli kontrola ta dotyczy podatku od wydobycia niektórych kopalin. Upoważniono również organy podatkowe do przekazywania akt spraw podatkowych dotyczących tego podatku organom nadzoru górniczego w celu weryfikacji pomiaru urobku rudy miedzi ${ }^{15}$.

\section{ZAKRES PRZEDMIOTOWY PODATKU I OBOWIĄZEK PODATKOWY}

Zakres przedmiotowy opodatkowania obejmuje wydobycie dwóch rodzajów kopalin: miedzi i srebra. W myśl przepisów ustawy przez wydobycie miedzi oraz srebra rozumieć należy wydobycie urobku rudy miedzi albo wydobycie urobku rudy miedzi i produkcje koncentratu ${ }^{16}$. Urobek rudy miedzi to kopalina wydobyta ze złóż położonych na terytorium Rzeczypospolitej Polskiej, zawierająca miedź lub srebro $\mathrm{w}$ ilościach nadających się do przemysłowego wykorzystania, koncentrat zaś definiowany jest jako produkt wzbogacania urobku rudy miedzi w postaci zdatnej do dalszego przetwarzania w procesach hutniczych ${ }^{17}$. Podkreślić należy, że przyjęta konstrukcja odpowiada istniejącym warunkom technologicznym, w których wydobyte w zakładach górniczych rudy miedzi kierowane są do zakładów wzbogacania rudy, gdzie poddawane sa procesowi przeróbki, w wyniku którego otrzymywany jest koncentrat o zawartości metalu umożliwiającej jego przetwarzanie metalurgiczne ${ }^{18}$. W wyniku metalurgicznego przetwórstwa koncentratów, a następnie procesu elektrorafinacji miedzi anodowej otrzymuje się srebronośne szlamy anodowe o zawartości od 35 do $50 \%$ srebra $^{19}$. Warto także zwrócić uwagę, że w trakcie prac parlamentarnych regulacje normujące zakres przedmiotowy podatku uzupełniono o przepis, w myśl którego opodatkowaniu nie podlega urobek

\footnotetext{
${ }^{13}$ W myśl art. 22 ustawy z 9 czerwca 2011 r. - Prawo geologiczne i górnicze (Dz. U. Nr 163, poz. 981 z późn. zm.) koncesji na poszukiwanie, rozpoznawanie oraz wydobywanie miedzi i srebra udziela minister właściwy do spraw środowiska. Koncesji udziela się na czas oznaczony, nie krótszy niż 3 lata i nie dłuższy niż 50 lat, chyba że przedsiębiorca złożył wniosek o udzielenie koncesji na czas krótszy. Koncesja uprawnia do wykonywania działalności gospodarczej w oznaczonej przestrzeni.

${ }^{14}$ Art. 12 ustawy o podatku od wydobycia niektórych kopalin.

${ }^{15}$ Art. $282 \mathrm{c} \S 1$ pkt 1 lit. h oraz art. 298 pkt 6c ustawy z 29 sierpnia 1997 r. - Ordynacja podatkowa, t.jedn.: Dz. U. 2005, Nr 8, poz. 60 ze zm. (dalej jako: Ordynacja podatkowa).

${ }^{16}$ Art. 2 pkt 2 ustawy o podatku od wydobycia niektórych kopalin.

${ }^{17}$ Art. 2 pkt 1 i 3 ustawy o podatku od wydobycia niektórych kopalin.

${ }^{18}$ Zob. uzasadnienie projektu ustawy o podatku od wydobycia niektórych kopalin, druk sejmowy nr 144.

${ }^{19}$ Ibidem.
} 
miedzi w ilości nieprzekraczającej 1 tony miesięcznie, jeżeli został wykorzystany na cele badawcze.

Konkretyzacja przedmiotu podatku jest podstawa opodatkowania. W wypadku podatku od niektórych kopalin konkretyzacja ta ma charakter ilościowy, przy czym co do zasady podstawa opodatkowania jest ilość miedzi wyrażona w tonach oraz ilość srebra wyrażona w kilogramach, zawarta w wyprodukowanym koncentracie. Jedynie wtedy, gdy podatnik nie produkuje koncentratu $\mathrm{z}$ wydobytego urobku, podstawę opodatkowania stanowi ilość miedzi oraz srebra zawarta w urobku rudy miedzi ${ }^{20}$.

Analogiczne założenie przyjęto, określając moment powstania obowiązku podatkowego. Również i w tym wypadku zasadnicze znaczenie ma dzień wyprodukowania koncentratu $\mathrm{z}$ wydobytego przez podatnika urobku rudy miedzi. W sytuacji gdy podatnik nie produkuje koncentratu, obowiązek podatkowy powstaje w dniu wydobycia samego urobku. Ponadto ustawa przewiduje, że w sytuacji, w której nie można określić dnia powstania obowiązku podatkowego w związku z wyprodukowaniem koncentratu albo wydobyciem urobku, za dzień jego powstania uznaje się dzień, w którym organ podatkowy lub organ kontroli skarbowej stwierdził dokonanie czynności podlegającej opodatkowaniu ${ }^{21}$. Dodać należy, że zobowiązanie podatkowe w podatku od wydobycia niektórych kopalin powstaje z mocy samego prawa, podatnik zaś zobowiązany jest bez wezwania obliczać i wpłacać podatek na rachunek właściwej izby celnej za miesięczne okresy rozliczeniowe, w terminie do 25 . dnia miesiąca następującego po miesiącu, w którym powstał obowiązek podatkowy ${ }^{22}$. Do podatku od wydobycia niektórych kopalin będzie miała zatem zastosowanie przewidziana $\mathrm{w}$ przepisach ogólnego prawa podatkowego zasada, zgodnie z która jeżeli przepisy prawa podatkowego nakładaja na podatnika obowiązek złożenia deklaracji, a zobowiązanie podatkowe powstaje ex lege, podatek wskazany w deklaracji jest podatkiem do zapłaty, chyba że organ podatkowy w postępowaniu podatkowym zakwestionuje jego wysokośćc ${ }^{23}$.

Obok obowiązku zapłaty podatku ustawa nakłada na podatników podatku od wydobycia niektórych kopalin szereg obowiązków o charakterze instrumentalnym. Podmioty te zobowiązane sa do składania, bez wezwania ze strony organu podatkowego, deklaracji podatkowej według wzoru określonego przez ministra finansów ${ }^{24}$. Ponadto ciąży na nich obowiązek dokonywania odpowiednich pomiarów oraz prowadzenia ewidencji tych pomiarów. Podatnicy produkujacy koncentrat $\mathrm{z}$ urobku rudy miedzi zobowiązani są do pomiaru każdego dnia, w którym wyprodukowano koncentrat, ilości wyprodukowanego

${ }^{20}$ Art. 6 ustawy o podatku od wydobycia niektórych kopalin.

${ }^{21}$ Art. 5 ustawy o podatku od wydobycia niektórych kopalin.

${ }^{22}$ Art. 14 ustawy o podatku od wydobycia niektórych kopalin.

${ }^{23}$ Art. $21 \S 2$ Ordynacji podatkowej.

${ }^{24}$ Zgodnie $\mathrm{z}$ treścią przedłożonego projektu rozporządzenia Ministra Finansów w sprawie wzoru deklaracji dla podatku od wydobycia niektórych kopalin podatnicy zobowiązani będą do składania deklaracji P-KOP. Dla obliczenia kwot podatku od poszczególnych wyrobów wymagane będzie wskazanie: nazw grup wyrobów, dla których ustalono odrębne stawki podatkowe, ceny z obwieszczenia w sprawie średniej ceny jednej tony miedzi oraz średniej ceny jednego kilograma srebra, podstawy opodatkowania wyrażonej odpowiednio w tonach lub kilogramach, stawek podatku oraz kwot podatku; zob. uzasadnienie projektu ustawy o podatku od wydobycia niektórych kopalin, druk sejmowy nr 144 . 
koncentratu oraz zawartości miedzi i srebra w tym koncentracie. Odpowiednio podatnicy nieprodukujacy koncentratu z urobku rudy miedzi zobowiązani są do pomiaru każdego dnia, w którym wydobyto urobek, ilości tego urobku oraz zawartości w nim miedzi i srebra. Na podatnikach ciąży również obowiązek pobierania każdego dnia, w którym wyprodukowano koncentrat lub urobek, próbek na zawartość srebra $\mathrm{w}$ koncentracie lub urobku rudy miedzi oraz pomiaru tej zawartości za każdy miesiąc na podstawie pobranych próbek dziennych ${ }^{25}$. Pomiarów zawartości miedzi i srebra w koncentracie lub urobku rudy miedzi dokonuje się zgodnie $\mathrm{z}$ metodykami badawczymi zatwierdzonymi przez krajową jednostkę akredytująca, czyli Polskie Centrum Akredytacji ${ }^{26}$. Ponieważ przeprowadzenie wskazanych pomiarów jest niezbędne do określenia ilości (masy) wydobytej miedzi i srebra, czyli dla określenia podstawy opodatkowania, niewywiązywanie się z tych obowiązków opatrzono sankcjami karnymi ${ }^{27}$.

Na podatników podatku od wydobycia niektórych kopalin nałożono również obowiązek dokumentowania i ewidencjonowania wyników dokonanych pomiarów oraz przechowywania stosownych dokumentów do czasu upływu okresu przedawnienia zobowiązania podatkowego ${ }^{28}$. Ustawa przewiduje, że ewidencja może być prowadzona w formie elektronicznej, szczegółowy zaś zakres danych, jaki powinna zawierać, określi minister finansów w drodze rozporządzenia. Wypada odnotować, że w myśl przedłożonego projektu rozporządzenia ewidencja winna zawierać: dane dotyczące dziennej ilości urobku rudy miedzi, zawartości miedzi i srebra w tym urobku, dziennej ilości wyprodukowanego koncentratu oraz zawartości miedzi i srebra w tym koncentracie z wyszczególnieniem ilości wydobytej kopaliny lub wyprodukowanego koncentratu oraz ilości miedzi lub srebra zawartego w wydobytej kopalinie lub wyprodukowanym koncentracie, a także daty wydobycia urobku rudy miedzi lub wydobytego koncentratu. Projekt rozporządzenia przewiduje również możliwość dokumentowania powyższych danych $\mathrm{w}$ ramach innej ewidencji stosowanej przez podatnika do celów związanych z prowadzoną działalnością gospodarczą ${ }^{29}$.

${ }^{25}$ Art. 15 ustawy o podatku od wydobycia niektórych kopalin.

${ }^{26}$ Zgodnie z art. 1 ust. 1 pkt 4 ustawy z 30 sierpnia 2002 r. o systemie zgodności (t.jedn.: Dz. U. 2010, Nr 138, poz. 935 ze zm.) zadania krajowej jednostki akredytującej w rozumieniu art. 2 pkt 11 rozporządzenia Parlamentu Europejskiego i Rady (WE) nr 765/2008 z 9 lipca 2008 r. ustanawiającego wymagania w zakresie akredytacji i nadzoru rynku odnoszące się do warunków wprowadzania produktów do obrotu i uchylającego rozporządzenie (EWG) nr 339/93 (Dz. Urz. UE L 218 z 13 sierpnia 2008 r., s. 30) realizuje Polskie Centrum Akredytacji.

${ }^{27}$ Do ustawy z 10 września 1999 r. - Kodeks karny skarbowy (Dz. U. 2007, Nr 111, poz. 765 ze zm.) dodano przepisy, w myśl których sankcjonowane są uchybienia polegające na: niedokonywaniu pomiarów zawartości miedzi i srebra w urobku rudy lub koncentracie, dokonywaniu tych pomiarów z naruszeniem przepisów ustawy, nieprowadzeniu ewidencji pomiarów lub prowadzeniu tej ewidencji w sposób nierzetelny, a także na prowadzeniu działalności w zakresie wydobycia miedzi lub srebra bez przeprowadzenia urzędowego sprawdzenia.

${ }^{28}$ Art. 16 ustawy o podatku od wydobycia niektórych kopalin.

${ }^{29}$ Zob. uzasadnienie projektu ustawy o podatku od wydobycia niektórych kopalin, druk sejmowy nr 144. 


\section{STAWKI I SKALE PODATKU}

Elementem konstrukcji podatku od wydobycia niektórych kopalin, który wzbudza największe kontrowersje zarówno w środowisku ekspertów podatkowych, jak i znawców problematyki gospodarki surowcami mineralnymi, jest sposób ustalania wysokości tej daniny, a w szczególności struktura stawek podatkowych. Stawki te mają charakter kwotowy i ustalane są odrębnie dla jednej tony wydobytej miedzi oraz jednego kilograma wydobytego srebra. W przeciwieństwie do stawek kwotowych obowiązujących na gruncie innych podatków wysokość stawki podatku od wydobycia niektórych kopalin oblicza się każdorazowo według zawartego w ustawie wzoru. Należy przy tym zwrócić uwagę, że przepisy przewidują dwa algorytmy obliczania stawek podatku od wydobycia miedzi, stosowane w zależności od tego, czy średnia cena miedzi przekracza 15000 zł za tonę, czy kształtuje się na poziomie niższym, oraz odpowiednio dwa algorytmy obliczania stawek od wydobycia srebra - stosowane w zależności od tego, czy średnia cena srebra przekracza lub nie przekracza 1200 zł za kilogram ${ }^{30}$. Ponadto $\mathrm{w}$ ustawie ustalono maksymalne i minimalne limity stawek podatkowych, które wynoszą:

a) 16000 zł za tonę miedzi (stawka maksymalna) i 0,5\% średniej ceny miedzi (stawka minimalna);

b) 2100 zł za kilogram srebra (stawka maksymalna) i 0,5\% średniej ceny srebra (stawka minimalna).

Przyjęcie powyższych rozwiązań oznacza, że w okresie gdy na rynkach międzynarodowych notowane sa wysokie ceny miedzi i srebra, skala w podatku od wydobycia niektórych kopalin będzie miała charakter progresywny. Podkreślić przy tym należy, że w konstrukcji analizowanego podatku wykorzystano niestosowaną na gruncie dotychczasowych przepisów tak zwaną progresję potęgową. Ponieważ średnie ceny miedzi i srebra podnoszone będą do potęgi (odpowiednio 2,5 i 4) w wypadku wysokich cen na rynkach światowych, stawka podatku będzie wzrastała szybciej niż przychody uzyskiwane ze sprzedaży metali. Po osiagnięciu przez średnią cenę miedzi kwoty około 46000 zł za tonę stawka podatku ukształtuje się na poziomie maksymalnym, to jest $16000 \mathrm{zł}$ za tonę miedzi. W przypadku srebra stawka maksymalna stosowana będzie w sytuacji, gdy średnia cena tego kruszcu wyniesie około 6000 zł za kilogram. $\mathrm{Z}$ kolei w okresie dekoniunktury, gdy średnia cena miedzi nie przekracza 15000 zł za tonę, a średnia cena srebra -1200 zł za kilogram, opodatkowanie będzie miało charakter proporcjonalny, przy czym stawka nie może wynieść mniej niż $0,5 \%$ średniej ceny metalu. Warto także zwrócić uwagę, że określone w ustawie kwoty graniczne ( 15000 zł za tonę miedzi oraz 1200 zł za kg srebra) oraz kwoty stanowiące element kalkulacyjny niezbędny do obliczenia stawki podatkowej podlegają w każdym roku kalendarzowym podwyższeniu w stopniu odpowiadającym wskaźnikowi wzrostu cen towarów i usług konsumpcyjnych $\mathrm{w}$ roku poprzedzającym rok waloryzacji w stosunku do roku poprzedniego ${ }^{31}$.

\footnotetext{
${ }^{30}$ Art. 7 ust. 2-5 ustawy o podatku od wydobycia niektórych kopalin.

${ }^{31}$ Zrewaloryzowane kwoty (wyrażone w złotych $\mathrm{z}$ pominięciem groszy) ogłaszane są w drodze obwieszczenia wydawanego przez ministra finansów w porozumieniu z Prezesem Głównego Urzędu Statystycznego, w terminie do 20 stycznia danego roku.
} 
Jeżeli wskaźnik ten ma wartość ujemną, wskazane kwoty nie ulegają zmianie. Waloryzacji nie podlegają natomiast maksymalne stawki podatku ${ }^{32}$.

Zgodnie z treścią ustawy średnia cena tony miedzi oraz średnia cena kilograma srebra ustalana jest w relacji do kursów notowań metali na rynkach światowych oraz kursu dolara amerykańskiego ${ }^{33}$. Zatem określenie ceny miedzi następować będzie z uwzględnieniem średniej arytmetycznej dziennych notowań miedzi ustalanych na Londyńskiej Giełdzie Metali (London Metal Exchange) w poprzednim miesiącu ${ }^{34}$, natomiast określenie ceny srebra - na podstawie średniej arytmetycznej notowań srebra ustalonych w Londyńskim Stowarzyszeniu Rynku Kruszców (London Bullion Market Association), również $\mathrm{w}$ poprzednim miesiącu ${ }^{35}$. W związku z powyższym minister finansów zobowiązany został do ogłaszania, w drodze obwieszczenia, w terminie do 10 . dnia każdego miesiąca średniej ceny tony miedzi oraz średniej ceny kilograma srebra za poprzedni miesiąc ${ }^{36}$.

W ustawie zawarto także przepisy, które w założeniu umożliwić maja ustalenie wysokości podatku w przypadku wystąpienia zdarzeń losowych zakłócających ciągłość funkcjonowania giełdy, a także likwidacji bądź transformacji podmiotu ustalającego notowania ${ }^{37}$. W sytuacji gdy notowania miedzi lub srebra w ogóle nie zostały ustalone, do obliczania wysokości podatku przyjmuje się średnią cenę tony miedzi lub średnią cenę kilograma srebra ogłoszona w ostatnim obwieszeniu. Z kolei w przypadku gdyby Londyńska Giełda Metali lub Londyńskie Stowarzyszenie Rynku Kruszców zmieniły nazwę, zostały przekształcone lub przejęte, kontynuując notowania miedzi i srebra, za podstawę obliczenia średniej arytmetycznej dziennych notowań należałoby uznać notowania prowadzone bądź przez te podmioty pod zmieniona nazwą lub w nowej formie prawnej, bądź przez ich następców prawnych. Analogiczna reguła znajdzie zastosowanie w razie zmiany nazwy notowania. Jednocześnie minister finansów upoważniony został do ogłoszenia w powyższych sytuacjach aktualnej nazwy odpowiednio podmiotu dokonującego notowań lub samego notowania ${ }^{38}$.

W myśl przepisów ustawy wysokość podatku obliczana jest jako suma iloczynów ilości miedzi wyrażonej w tonach i stawki ustalonej zgodnie z określonym wzorem oraz ilości srebra wyrażonej w kilogramach i stawki podatku obliczonej według zawartego w ustawie wzoru ${ }^{39}$. Oznacza to, że wysokość podatku uzależniona jest przede wszystkim od wartości surowców na rynku światowym, kursu dolara amerykańskiego, w którym notowane są miedź

${ }^{32}$ Art. 9 ust. 1 ustawy o podatku od wydobycia niektórych kopalin.

${ }^{33}$ Art. 8 ustawy o podatku od wydobycia niektórych kopalin.

${ }^{34}$ Średnia arytmetyczna dziennych notowań miedzi wyrażona będzie w dolarach amerykańskich za tonę, w zaokrągleniu w górę, z dokładnością do jednego centa amerykańskiego.

${ }^{35}$ Średnia arytmetyczna dziennych notowań srebra wyrażona będzie w dolarach amerykańskich za uncję w zaokragleniu w górę, z dokładnością do jednego centa amerykańskiego. Jednocześnie w ustawie przyjęto, że kilogram zawiera 32,15 uncji.

${ }_{36}$ Srednie ceny miedzi i srebra wyrażone będą w złotych, z pominięciem groszy.

${ }^{37}$ Zob. uzasadnienie projektu ustawy o podatku od wydobycia niektórych kopalin, druk sejmowy nr 144.

${ }^{38}$ Art. 8 ust. 2 i art. 10 ustawy o podatku od wydobycia niektórych kopalin.

${ }^{39}$ Art. 7 ustawy o podatku od wydobycia niektórych kopalin. 
i srebro oraz wielkości wydobycia. Na szczególną uwagę zasługuje fakt, że kwot uiszczonych z tytułu podatku od wydobycia niektórych kopalin nie uważa się za koszty uzyskania przychodów w podatkach dochodowych ${ }^{40}$.

W ocenie projektodawców przyjęta metoda ustalania podatku równoważy dochody budżetowe $\mathrm{z}$ tytułu tej daniny z zyskami podmiotów wydobywających miedź i srebro, co powinno pozwolić nie tylko utrzymać, lecz także zwiększyć produkcję górniczą ${ }^{41}$. W piśmiennictwie konstrukcja ta budzi jednak wiele wątpliwości. Po pierwsze wskazuje się, że sposób kalkulacji podatku od kopalin powinien uwzględniać koszty wytworzenia oraz przerobu miedzi i srebra. Przyjęcie takiego rozwiązania umożliwiłoby uwzględnienie zróżnicowanej efektywności wydobycia z konkretnych złóż i nie zniechęcałoby do inwestycji wymagających wielomilionowych nakładó ${ }^{42}$. Podnosi się również, że opodatkowanie wydobycia może skutkować ograniczeniem wykorzystania zasobów złóż w dłuższej perspektywie czasowej poprzez niepełne wykorzystanie udokumentowanych zasobów i skrócenie żywotności kopaln ${ }^{43}$. Zdaniem ekspertów bardziej korzystne byłoby rozwiązanie, w którym zamiast masy wydobytego surowca opodatkowaniu podlegałby zysk $\mathrm{z}$ jego sprzedaż $^{44}$, a $\mathrm{w}$ kalkulacji wysokości podatku byłyby uwzględnione inwestycje ${ }^{45}$.

Druga wątpliwość dotyczy wyłączenia z kosztów uzyskania przychodów kwot uiszczonego podatku od wydobycia niektórych kopalin. W ocenie projektodawców dzięki takiemu rozwiązaniu możliwe będzie pozostawienie na niepogorszonym poziomie dochodów jednostek samorządu terytorialnego z tytułu udziałów w podatkach dochodowych ${ }^{46}$. Trudno jednak nie zgodzić się $\mathrm{z}$ wyrażanym przez ekspertów poglądem, że podatek od wydobycia niektórych kopalin powinien być uznany za koszt uzyskania przychodu, w przeciwnym razie dochodzi bowiem do podwójnego opodatkowania tej samej wartości ${ }^{47}$. Ponadto pojawia się ryzyko spadku inwestycji oraz zahamowania poszukiwań nowych złóż przez spółki miedziowe. Warto także zwrócić uwagę, że w opinii Departamentu Rachunkowości Ministerstwa Finansów podatek od wydobycia niektórych kopalin, ze względu na to, że uzależniony jest od ilości miedzi oraz srebra zawartej w wyprodukowanym koncentracie lub urobku, powinien zostać uznany za element kosztu wytworzenia produktu w rozumieniu ustawy

${ }^{40}$ Art. 16 ust. 1 pkt 67 ustawy z 15 lutego 1992 r. o podatku dochodowym od osób prawnych (t.jedn.: Dz. U. 2011, Nr 74, poz. 397 ze zm.) oraz art. 23 ust. 1 pkt 62 ustawy z 26 lipca 1991 r. o podatku dochodowym od osób fizycznych (t.jedn.: Dz. U. 2012, poz. 361).

${ }^{41}$ Zob. uzasadnienie projektu ustawy o podatku od wydobycia niektórych kopalin, druk sejmowy nr 144.

${ }^{42}$ Zob. K. Czarnecka-Żochowska, J. Woźniak, Jeszcze o gazie tupkowym, „Rzeczpospolita” z 2 kwietnia 2012 r.

${ }^{43}$ Zob. M. Nieć, Uwagi do podatku od kopalin, „Rzeczpospolita” z 7-9 kwietnia 2012 r.

${ }^{44}$ Zob. K. Czarnecka-Żochowska, J. Woźniak, op. cit.

${ }^{45}$ Zob. Instytut Jagielloński za innym podatkiem od wydobycia miedzi i srebra, „Gazeta Prawna” z 9 lutego 2012 r. Zob. także H. A. Janiszewski, Czy warto zarzynać kure..., „Rzeczpospolita” z 3 lutego $2012 \mathrm{r}$.

${ }^{46}$ Zob. uzasadnienie projektu ustawy o podatku od wydobycia niektórych kopalin, druk sejmowy nr 144.

${ }^{47}$ Zob. Deloitte: polski model podatku miedziowego wyjatkowo restrykcyjny, „Gazeta Prawna” z 25 stycznia 2012 r. Najpierw opodatkowaniu podlegają wydobyte miedź i srebro, a następnie - dochód uzyskany ze zbycia tych metali. 
o rachunkowości ${ }^{48}$. Jednoczesne wyłączenie tej daniny z kosztów uzyskania przychodów oznacza obowiązek prowadzenia odrębnej ewidencji kosztów dla celów rachunkowych i ustalenia podstawy opodatkowania podatkami dochodowymi ${ }^{49}$.

Kolejna kwestia budząca wątpliwości w doktrynie jest zgodność regulacji dotyczących sposobu ustalania stawek podatku od wydobycia niektórych kopalin z konstytucyjną zasadą wyłączności ustawy w sferze prawa daninowego ${ }^{50}$. Z jednej strony wskazuje się, że stworzona w analizowanej ustawie konstrukcja określania stawek podatkowych oznacza w istocie upoważnienie do kształtowania ich wysokości przez rynki finansowe, a „,uzależnienie podatków i stawek podatkowych od kursów walut i notowań giełdowych pozbawia znaczenia konstytucyjny wymóg regulowania tych materii w ustawie, stanowiąc zaprzeczenie wyrażonego w orzecznictwie Trybunału Konstytucyjnego poglądu, że regulacja ustawowa zyskuje w przypadku kwestii podatkowych zupełny charakter" ${ }^{51}$. Z drugiej strony wyrażany jest pogląd, że przyjęty sposób regulacji nie narusza norm konstytucyjnych, precyzyjne zaś określenie stawki procentowej podatku od wydobycia niektórych kopalin nie realizowałoby celu ustawy, gdyż sztywna stawka nie uwzględniałaby koniunktury na rynku metali ${ }^{52}$.

Trybunał Konstytucyjny w swoim orzecznictwie wielokrotnie podkreślał, że w myśl art. 217 Konstytucji RP wszystkie istotne elementy stosunku daninowego powinny być uregulowane bezpośrednio w ustawie, a do unormowania w drodze rozporządzenia moga zostać przekazane tylko te sprawy, które nie mają istotnego znaczenia dla konstrukcji danej daniny ${ }^{53}$. W ocenie Trybunału

${ }^{48}$ Zob. A. Pokojska, Wysokość podatku od kopalin należy ewidencjonować $w$ księgach rachunkowych jako koszt wytworzenia, ,Gazeta Prawna” z 2 kwietnia 2012 r. W myśl art. 28 ust. 3 ustawy z 29 września 1994 r. o rachunkowości (t.jedn.: Dz. U. 2009, Nr 152, poz. 1223 ze zm.) koszt wytworzenia produktu obejmuje koszty pozostające w bezpośrednim związku z danym produktem oraz uzasadnioną część kosztów pośrednio związanych $\mathrm{z}$ wytworzeniem danego produktu. Koszty bezpośrednie obejmuja m.in. koszty pozyskania i przetworzenia związane bezpośrednio z produkcją i inne koszty poniesione w związku z doprowadzeniem produktu do postaci i miejsca, w jakich się znajduje w dniu wyceny.

49 Szerzej zob. A. Pokojska, Ksiegowanie podatku od kopalin będzie trudne, „Gazeta Prawna” z 12 marca 2012 r.

${ }^{50}$ Art. 217 Konstytucji Rzeczypospolitej Polskiej z 2 kwietnia 1997 r. (Dz. U. Nr 78, poz. 483, sprost. Dz. U. 2001, Nr 28, poz. 319 ze zm.).

${ }^{51}$ R. Piotrowski, Opinia o zgodności z Konstytucja RP ustawy z dnia 2 marca 2012 r. o podatku od wydobycia niektórych kopalin (druk senacki nr 66), „Opinie i Ekspertyzy” OE-185, marzec 2012, s. 30-31. Zob. także M. Reszczyński, Opinia do ustawy o podatku od wydobycia niektórych kopalin (druk 66), www.senat.gov.pl.

${ }^{52}$ Zob. M. Chmaj, Opinia prawna $w$ przedmiocie oceny zgodności $z$ Konstytucja ustawy $z$ dnia 2 marca 2012 r. o podatku od wydobycia niektórych kopalin (druk senacki nr 66), „Opinie i Ekspertyzy” OE-185, marzec 2012, s. 15-16.

${ }^{53}$ Zob. wyroki TK: z 16 czerwca 1998 r., U 9/97, OTK ZU 1998, nr 4, poz. 51; z 1 września 1998 r., U 1/98, OTK ZU 1998, nr 5, poz. 65; z 9 lutego 1999 r., U 4/98, OTK ZU 1999, nr 1, poz. 4. Szerzej na temat wyłączności ustawy w sferze prawa daninowego zob także. C. Kosikowski, Źródta prawa podatkowego $w$ świetle Konstytucji RP, „Glosa” 1999, nr 7, s. 1-3; H. Dzwonkowski, Elementy konstrukcyjne podatku w świetle art. 217 Konstytucji, ,Glosa” 1999, nr 6, s. 1-6; J. Kulicki, Konstytucyjne podstawy nakładania podatków (zarys wybranych problemów), „Prawo Spółek” 2000, nr 3, s. 51-54; R. Zalewiański, Artykut 217 Konstytucji RP w praktyce podatkowej, w: R. Mastalski (red.), Ksiega jubileuszowa Profesora Marka Mazurkiewicza. Studia z dziedziny prawa finansowego, prawa konstytucyjnego i ochrony środowiska, Wrocław 2001, s. 333-348. 
celem zasady wyłączności ustawy w sferze prawa daninowego jest nie tylko stworzenie gwarancji praw podatnika wobec organów władzy publicznej, lecz także przede wszystkim wzmocnienie pozycji demokratycznych struktur przedstawicielskich i ich odpowiedzialności politycznej ${ }^{54}$. Trybunał zwrócił także uwagę, że: „z tych samych względów, dla których niedopuszczalne jest odsyłanie w tej materii do aktów wykonawczych, jako naruszenie wymagań konstytucyjnych oceniać należy takie niejasne i nieprecyzyjne formułowanie przepisu, które powoduje niepewność jego adresatów co do ich praw i obowiązków. Powoduje ono bowiem stworzenie nazbyt szerokich ram dla organów stosujących taki przepis, które $\mathrm{w}$ istocie muszą zastępować prawodawcę $\mathrm{w}$ zakresie tych zagadnień, które uregulował on w sposób niejasny i nieprecyzyjny" ${ }^{55}$.

Przepisy określające zasady ustalania stawek podatku od wydobycia niektórych kopalin nie odsyłaja $\mathrm{w}$ tym zakresie do materii rozporządzenia. Kontrowersje budzi natomiast fakt, że wskazany element konstrukcji podatku ustalony jest nie jako w wartość bezwzględna, ale w relacji do średniej ceny miedzi i srebra. Średnia cena miedzi i srebra uzależniona jest z kolei od wskazanych w ustawie zmiennych, to jest średniej arytmetycznej średnich kursów dolara amerykańskiego do złotego ogłoszonych przez Narodowy Bank Polski w poprzednim miesiącu oraz odpowiednio średniej arytmetycznej dziennych notowań miedzi lub średniej arytmetycznej dziennych notowań srebra ustalanych na wskazanych w ustawie giełdach. Ustawa o podatku od wydobycia niektórych kopalin w sposób szczegółowy określa przy tym nazwy notowań relewantnych z punktu widzenia ustalania wysokości stawek oraz podmioty dokonujące tego rodzaju notowań. Ponadto w drodze ustawowej określone zostały zasady zaokraglania powyższych wartości i co szczególnie istotne wysokość stawek minimalnych i maksymalnych. Podkreślić przy tym należy, że zmienne uwzględniane $\mathrm{w}$ procesie obliczania stawki mają charakter obiektywny: ustalane sa przez wolny rynek, a minister finansów dokonuje jedynie ich ogłoszenia $\mathrm{w}$ drodze obwieszczenia. W związku $\mathrm{z}$ powyższym stwierdzić należy, że konstrukcja norm zawartych w ustawie o podatku od wydobycia niektórych kopalin czyni zadość konstytucyjnemu wymogowi, zgodnie z którym ustawa podatkowa musi być tak skonstruowana, by dla wszystkich podmiotów objętych jej działaniem kwota podatku w tych samych warunkach przedmiotowych i przy takiej samej podstawie była taka sama ${ }^{56}$. Stosując analizowane przepisy, można bowiem kalkulować przyszły podatek i zachować pewność, że ani akt podustawowy, ani interpretacja przepisów ustawy nie moga być na tyle swobodne, by pogorszyły sytuację prawna podatników ${ }^{57}$. Na marginesie powyższych rozważań warto także zwrócić uwagę, że zastosowana $\mathrm{w}$ analizowanej ustawie metoda ustalania współczynnika, za pomocą którego obliczana jest wielkość ciężaru finansowego w relacji do

${ }^{54}$ Zob. wyrok TK z 8 grudnia 2009 r., K 7/08, Dz. U. Nr 215, poz. 1674.

${ }^{55}$ Wyrok TK z 22 maja 2002 r., K 6/02, OTK ZU 2002, nr 3, poz. 33.

${ }^{56}$ Zob. T. Dębowska-Romanowska, Prawo finansowe. Część konstytucyjne wraz z częścia ogólna, Warszawa 2010, s. 144.

${ }^{57}$ Zob. T. Dębowska-Romanowska, Dylematy interpretacyjne artykutu 217 Konstytucji, w: A. Gomułowicz, A. Małecki (red.), Ex iniuria non oritur ius. Księga ku czci Profesora Wojciecha Eaczkowskiego, Poznań 2003, s. 220. 
zmiennych niezależnych od woli ustawodawcy, nie jest na gruncie prawa podatkowego rozwiązaniem zupełnie nowym. W analogiczny sposób ustalana jest bowiem wysokość stawek odsetek za zwłokę od zaległości podatkowych ${ }^{58}$.

W literaturze przedmiotu podkreśla się, że konstytucyjny wymóg określoności i czytelności normy podatkowej wiąże się z możliwością przewidywania przyszłych kwot podatku, ustawodawca zaś odpowiada za taki stopień czytelności normy prawnej, który uwzględnia potencjalny minimalny stan świadomości prawnej, niezbędny do prawidłowego funkcjonowania społecznego i gospodarczego kategorii podmiotów objętych danym prawnopodatkowym stanem faktycznym ${ }^{59}$. W wypadku podatku od wydobycia niektórych kopalin możliwość przewidywania przyszłych kwot podatku, a w konsekwencji odpowiedniego kształtowania swoich interesów, uzależniona jest przede wszystkim od znajomości rynku tych surowców. Rozwiązanie to niewątpliwie należy uznać za kontrowersyjne. W założeniu przewidywalność, o której mowa w art. 217 Konstytucji RP, powinna być bowiem bliska poznawalności przyszłej kwoty podatku $^{60}$, co $\mathrm{w}$ przypadku zmiennych, jakimi sa kursy walut i notowania metali, wydaje się wątpliwe. Uzasadnienia takiej konstrukcji upatrywać natomiast można $\mathrm{w}$ charakterze podmiotów będących potencjalnymi podatnikami wprowadzanej daniny. Sa to bowiem podmioty profesjonalne, de facto jedna spółka miedziowa od kilkunastu lat notowana na giełdzie, w odniesieniu do której można zakładać wysoki poziom świadomości prawnej i ekonomicznej. Należy również zwrócić uwagę, że w myśl przyjętych założeń ryzyko wynikające z wahań kursów i notowań zmniejszać maja ustalone w ustawie maksymalne i minimalne limity stawek.

\section{KONKLUZJE}

Przeprowadzone rozważania pozwalają na sformułowanie kilku następujących wniosków.

Po pierwsze, nie budzi wątpliwości fakt, że wprowadzony ustawą z 2 marca 2012 r. podatek od wydobycia niektórych kopalin stanowi na gruncie przepisów polskiego prawa podatkowego nową jakość. Jest to podatek od wielkości urobku (wydobycia), ustalany w relacji do wartości produkcji i w założeniu mający na celu uchwycenie nadzwyczajnych zysków podmiotów wydobywających miedź i srebro. O ile sama potrzeba wprowadzenia tego rodzaju daniny jest powszechnie akceptowana, o tyle konstrukcja poszczególnych elementów struktury podatku oceniana jest rozbieżnie.

${ }^{58} \mathrm{~W}$ myśl art. 56 § 1 Ordynacji podatkowej stawka odsetek za zwłokę jest równa sumie $200 \%$ podstawowej stopy oprocentowania kredytu lombardowego, ustalanej zgodnie z przepisami o Narodowym Banku Polskim, i $2 \%$, z tym że stawka ta nie może być niższa niż $8 \%$. Również i w tym wypadku wysokość stawek odsetek ogłaszana jest każdorazowo w drodze obwieszczenia ministra finansów.

${ }^{59}$ Zob. T. Dębowska-Romanowska, Obliczenie podatku a gwarancje praw obywatelskich, „Państwo i Prawo" 1998, z. 7, s. 27.

${ }^{60}$ Zob. T. Dębowska-Romanowska, Dylematy interpretacyjne..., s. 220. 
Po drugie, należy podkreślić, że wbrew podnoszonym zarzutom instrument ten nie ma charakteru indywidualnego. W płaszczyźnie językowej podatnikiem jest każda osoba fizyczna, osoba prawna lub jednostka organizacyjna nieposiadająca osobowości prawnej, dokonująca w zakresie prowadzonej działalności gospodarczej wydobycia miedzi oraz srebra, co oznacza, że norma zawarta w przepisie określającym zakres przedmiotowy podatku ma charakter generalny.

Po trzecie, zakres przedmiotowy opodatkowania obejmuje wydobycie jedynie dwóch rodzajów kopalin: miedzi i srebra, co oczywiście nie wyklucza w przyszłości wprowadzenia podatku, który dotyczyłby wydobycia na przykład gazu łupkowego. Podstawą opodatkowania jest wyrażona w tonach ilość miedzi oraz wyrażona w kilogramach ilość srebra zawarta w produkowanym koncentracie lub urobku rudy miedzi. Decyzję ustawodawcy o opodatkowaniu samej masy wydobytego surowca można oczywiście oceniać jako restrykcyjną i niekorzystną dla podatników, przyznać jednak należy, że zachowany został konstytucyjny wymóg wskazania mienia, z którego może być pokryty ciężar podatku.

Po czwarte, w podatku od wydobycia niektórych kopalin przyjęto specyficzną, niestosowaną na gruncie innych przepisów podatkowych, konstrukcję stawek i skal podatkowych. Stawki maja charakter kwotowy, przy czym ustalane są nie jako wartość bezwzględna, ale w relacji do średnich cen miedzi i srebra, które z kolei uzależnione są od kursów dolara oraz notowań tych kruszców ustalanych na wskazanych w ustawie giełdach. Wzory, według których obliczane są stawki, wskazują na to, że w okresie, gdy na rynkach międzynarodowych notowane sa wysokie ceny miedzi i srebra, skala jest progresywna (tzw. progresja potęgowa), natomiast w okresie dekoniunktury opodatkowanie będzie miało charakter proporcjonalny. Jednocześnie w ustawie określono poziom stawek maksymalnych i minimalnych.

W doktrynie kwestionowana jest zgodność regulacji dotyczących wskazanej metody ustalania stawek z konstytucyjną zasadą wyłączności ustawy w sferze prawa daninowego. W świetle przeprowadzonej analizy wydaje się jednak, że przepisy ustawy o wydobyciu niektórych kopalin umożliwiają obliczenie jednej i jedynej kwoty podatku, a uzależnienie wysokości stawek podatkowych od zmiennych kształtowanych przez wolny rynek należy uznać za wyraz woli politycznej ustawodawcy, świadomą decyzję z zakresu polityki podatkowej, w następstwie której nie tylko podatnicy, lecz także państwo jako wierzyciel podatkowy narażeni są na ryzyko związane z nieprzewidywalnością cen miedzi i srebra na rynkach światowych.

dr Michalina Duda

Katolicki Uniwersytet Lubelski Jana Pawta II 


\section{TAX ON THE EXTRACTION OF CERTAIN MINERALS - A NEW QUALITY IN THE POLISH TAX LAW}

\section{Summary}

On April 18, 2012, the Law on Taxation of Certain Minerals came into force. By virtue of this law, a new public levy, assumed to constitute a form of a resource rent, was introduced into the Polish law. The tax covers the extraction of two metals, namely copper and silver, and belongs to the group of levies that are imposed based on the volume of the mining output (extraction). The revenue from the new levy is supposed to constitute in its entirety the income of the state budget. According to the drafters of the law, the tax should make it possible to capture the outstanding profits of the entities that extract the metals in question. However, according to experts in the tax law and experts in the management of those resources, the structure of the levy in question raises doubts.

The aim of this paper is to present the technical elements of the Tax on the Extraction of Certain Minerals and the controversies related to the introduction of this levy. It discusses the subjective and the objective scope of the tax, the taxpayers' duties, as well as the normative structure of the tax rates and scales. 
Copyright of Journal of Law, Economics and Sociology is the property of Faculty of Law and Administration of Adam Mickiewicz University in Poznan and its content may not be copied or emailed to multiple sites or posted to a listserv without the copyright holder's express written permission. However, users may print, download, or email articles for individual use.

Właścicielem praw autorskich do „Ruchu Prawniczego, Ekonomicznego i Socjologicznego” jest Wydział Prawa i Administracji Uniwersytetu im. Adama Mickiewicza w Poznaniu. Zawartość czasopisma nie może być kopiowana, przesyłana do innych stron internetowych bądź zamieszczana na blogach bez pisemnej zgody wydawcy. Niemniej artykuły można drukować, kopiować lub przesyłać w formie elektronicznej na własny użytek. 